\title{
TRANSLATOR'S ABERRATIONS AS A CONSEQUENCE OF NON-PROTOTYPICALITY OF THE SOURCE POETIC SIGN
}

\section{ПЕРЕКЛАДАЦЬКІ АБЕРАЦІЇ ЯК НАСЛІДОК НЕПРОТОТИПІЧНОСТІ ВИХІДНОГО ПОЕТИЧНОГО ЗНАКА}

\section{Doubenko Elena ${ }^{1}$}

DOI: https://doi.org/10.30525/978-9934-571-78-7_28

Abstract. The article focuses on those worldview aspects of poetic imagery that present a considerable translation problem since such conceptually controversial elements of the source text may undergo different interpretations in poetic translation. The crux of the question seems to lie in the circumstance whether the conceptual content of a certain poetic sign in the source culture may be called prototypical for the poetic weltanschauung shared by the representatives of the target culture. The poetic material under discussion is considered in terms of the gestaltist methodology which conditions the necessity of considering the gestaltstructures of source poetic signs from the standpoint of their prototypicality in the recipient culture. The research leans upon two basic principles of gestalt theory that govern human perception - the law of prägnanz and the law of figure/ground. The novelty of the work is in employing a gestaltist approach to the interpretation of translatological issues concerning the conveyance of source imagery in poetic translation. The aim of the paper lies in describing those translation aberrations or image defects of worldview character found in the target poetic texts that take place in case the gestalt of the original poetic sign displays scarce prototypicality within the framework of the target cultural tradition. Translator's aberrations are defined as deviations from the source poetic text which take place in poetic translation owing to some specific ethnocultural and aesthetic features of the translator's world view. The translator's decisions that lead to certain tangible shifts in the conceptual content of the source text are presented from a cognitive standpoint. They are treated as an immediate consequence of those discrepancies in the source and target ethnocultural and aesthetic

${ }^{1}$ Doctor of Philosophy, Associate Professor,

Institute of Philology, Taras Shevchenko National University of Kyiv, Ukraine 


\section{Chapter «Philological sciences»}

codes that condition only relative translatability of the original poetic text. The findings of the article lie in presenting a comprehensive analysis of the deconstruction of the gestalt-structure of the source poetic sign in translation and the substitution of the source poetic sign in those cases when the translator's decision is predetermined by the influence of those poetic norms that have established themselves in the target culture. In a wider sense the conclusions drawn testify to the fact that gestaltist methods prove to be rather promising in studying the field of poetic translation.

\section{1. Ветуп}

Виявленню критеріїв, за якими можна судити про адекватність поетичного перекладу, присвячено багато праць вітчизняних та зарубіжних дослідників, як філологів, так і письменників. Такий інтерес до цієї проблематики є цілком закономірним, адже адекватність перекладу являє собою центральне, кульмінаційне питання перекладознавчих студій, що й зумовлює актуальність даної статті, спрямованої на з'ясування факторів, що впливають на ступінь адекватного відтворення вихідного поетичного образу у цільовому тексті. Очевидно, що при вирішенні вищезазначеного питання необхідно керуватися даними як стилістики декодування, так і генетичної стилістики, оскільки художній переклад має й етичний вимір. Етика перекладача полягає у вірності відтворення авторського світовідчуття, яке в свою чергу являє собою своєрідний сплав індивідуальних рис художньої свідомості поета зі стилем мислення епохи, певної картини світу на тлі якої ці риси сформувалися. У цьому зв'язку видається очевидним той факт, що перекладаючи поетичний текст необхідно брати до уваги певні історично зумовлені нюанси трактування його образності, тобто ті елементи змісту певного поетичних гештальтів, що належать до особливостей національної поетичної картини світу. Проте далеко не завжди це завдання виявляється здійсненим у практиці художнього i, зокрема, поетичного перекладу.

Адже текст будь-якого поетичного перекладу є продуктом перекладацької герменевтики, тобто наслідком інтерпретаційної діяльності творця цільового тексту, чия особистість сформувалася під впливом матриць концептуальної та поетичної картин світу цільової культури. Оскільки перекладач завжди є носієм певного загальнонаціонального світогляду, транслятором специфічних рис концептуальної та поетич- 


\section{Doubenko Elena}

ної картин світу культури реципієнта, достатньо суттєві відхилення від першотвору у тексті поетичного перекладу можуть бути наслідком розбіжностей не лише у системах вихідної та цільової мови, але й у менталітетних установках тих культурних традицій, до яких належать автор оригінального тексту та перекладач.

Мета цієї статті полягає в аналізі явища так званої перекладацької аберації, тобто відхилення від оригіналу, спровокованого впливом на свідомість перекладача домінант власної культури та власної естетичної традиції, пов'язаних з відмінностями у концептуальних і поетичних картинах світу вихідної та цільової культур. Досягнення цієї мети передбачає розв'язання таких завдань: 1) описати перекладацькі аберації, що мають місце при перекодуванні поетичного образу засобами цільової мови; 2) виявити вплив прототипічності гештальт-структури вихідного поетичного знаку на характер його трансмутацій у цільовому поетичному тексті. Методи дослідження зумовлені його метою та завданнями. Необхідність компаративного вивчення поетичних знаків вихідного та цільового тексту з урахуванням їх комбінаторних зв'язків у відповідних етнокультурних та етнопоетичних кодах визначило доцільність звертання до гештальтистської методології, яка дозволяе оперувати тими структурами поетичного смислу, в котрих залишається недоторканою цілісність художньої перцепції. Це закон фону/фігури та закон прегнантності. У статті також застосовані герменевтичний метод, метод концептуального аналізу, метод аналізу архетипів.

\section{2. Перекладацькі аберації у світлі гештальтистської теорії}

Теоретико-перекладацька гілка порівняльної поетики є скерованою на дослідження семіотичної природи поетичної картини світу і має на меті з'ясування шляхів відтворення внутрішньої семіотики певної культури засобами цільової мови, яка, по суті, є кодом інших семіотичних взаємозв'язків. Терміни зовнішня і внутрішня семіотика було запроваджено дослідником семасіологічних універсалій в індо-європейських мовах М.М. Маковським. При цьому під зовнішньою семіотикою розуміються засоби мовного здійснення комунікативного акту між мовцями, внутрішня ж семіотика описується як результат комбінування певних елементів мови у «безкінечних якісно і кількісно неоднакових послідовностях», внаслідок чого виникає «певний текст «генетичної інформації, який регулює та прогнозує можливі і немож- 


\section{Chapter «Philological sciences»}

ливі, обов'язкові й необов'язкові шляхи існування, співіснування та еволюції окремих ланок мовного механізму, накладають «заборони» на одні ділянки мовного простору і знімають їх з інших» [5, с. 7]. Хоча загальна схема слів (поєднання фоно-морфологічного комплексу зі значенням) є універсальною, кожне окреме слово тієї чи іншої мови являє собою унікальне утворення, організоване на основі притаманних лише йому комбінаторних схем, і має у зв'язку з цим унікальні якісні та кількісні властивості» [5, с. 9].

Завдяки такому розумінню природи слова поняття внутрішньої та зовнішньої семіотики можуть бути екстрапольованими в царину досліджень іншомовного втілення поетичного тексту. Зовнішня семіотика у цьому трактуванні корелюватиме з ситуацією міжмовної комунікації, а внутрішня семіотика являтиме собою той текст генетичної інформації, часткою якого $є$ досліджувальні гештальти першотвору, задані матрицями поетичної картини світу вихідної мови, які, своєю чергою, визначаються специфічними рисами відповідної мовної та концептуальної картини світу. Саме відмінності у тих комбінаторних схемах, що стали прототипічними для певних значимих художніх елементів у порівнюваних поетичних традиціях, базованих на різних етносеміотичних системах, мають наслідком проблеми перекладності образу або його представлення у термінах іншої внутрішньої семіотики. 3 позицій гештальт-теорії цї питання безпосередньо пов’язані з таким законом гештальту як тяжіння частин до створення симетричного цілого, а також так званою «прегнантністю», тобто тенденцією кожного психологічного явища до набуття більш чіткої, завершеної форми.

Закон прегнантності - це найбільш фундаментальний закон гештальт психології, що зосереджується на їдеї стислості, яка становить основу усієї гештальт-теорії, адже німецьке слово Prägnanz сумарно можна перекласти як «виразна лаконічність» (Prägnanz - влучність, виразність, чіткість, точність (висловлення); prägnant -1) влучний, виразний, чіткий, точний; 2) сповнений смислу, багатий змістом [2, с. 206]). Згадана ідея передбачає характер-ність, стислість та правильність (про поняття ґештальту як стислого опису див. [7 ]). Цей закон постулює, що при сприйнятті елементи об'єктів мають тенденцію до групування в єдине ціле, якщо конфігурація, яку вони утворюють, $є$ правильною, простою та добре організованою (збалансованою). Іншими словами, ми намагаємося сприймати речі у той спосіб, який 


\section{Doubenko Elena}

відповідає вимогам «хорошого» гештальту, тобто правильної, симетричної, упорядкованої форми, відмовляючись від ускладненого та незнайомого задля того, щоб споглядати реальність у ії найбільш спрощеному вигляді. Усуваючи все стороннє та чужорідне мозок створює смисл, який передбачає глобальну правильність.

Терміни «прегнатний гештальт», «прегнантна фігура» у значенні «хорошого», рівноважного гештальту, «кращої» фігури, що широко застосовуються у гештальтпсихології, запропоновано одним iз засновників теорії гештальтів К.Коффкою. Пізніше висновки, яких дійшли М.Вертгеймер та К.Коффка на основі дослідження сенсорної складової людської психіки, було екстрапольовано В.Келлером в царину досліджень мислення. Внаслідок цього розумовий процес постав як послідовне прикладання людиною «різних «структур бачення» (тобто гештальтів) до структури самої проблемної ситуації. Інсайт (прозріння) настає якраз тоді, коли у свідомості людини структури бачення збігаються зі структурою проблемної ситуації - тоді вона, власне, є вирішеною. Вирішена ж проблемна ситуація стає для індивіда прегнантною, тобто «хорошою» [1, с. 78].

Закон замкнутості (термін, впроваджений М.Вертгеймером $[10$, c. 83] як особливий, динамічний варіант закону прегнантності, визнається одним з базових принципів перцептуальної та ментальної організації. Незавершені форми сприймаються як цілісність, оскільки людська уява домальовує відсутні елементи, комбінуючи частини у цілісні форми. У ширшому сенсі, певні недосконалі цілісності - спогади, думки, вчинки - мають тенденцію до завершених замкнутих форм.

У цій ситуації свідомість читача як вихідного, так і цільового тексту зіштовхується з проблемою створення «хорошого», рівноважного гештальту - симетричного цілого, побудова якого регулюється з позицій гештальтпсихології законом «прегнантності», або тенденцією кожного психологічного явища до набуття більш чіткої, завершеної форми.

Закон прегнатності або принцип «хорошого гештальту» $є$ важливим методологічним інструментом когнітивної поетики перекладознавчого напряму. Справа в тому, що декодування художнього тексту як раз й являє собою один з прикладів реалізації «закону прегнантності», тобто цілеспрямованого прагнення людини до простих або чіткіх форм, до простих і стійких станів. 
Певне адаптування тексту художнього перекладу до очікувань цільової аудиторії, зумовлених специфікою концептуального простору культури реципієнта, становить базове професійне завдання перекладача художньої літератури. Адже провідна перекладацька мета при інтерпретації вихідного поетичного тексту полягає у передбаченні та усуненні тих труднощів розуміння першотвору, що можуть виникнути в носіїв цільової культури при сприйнятті оригінального тексту. 3 іншого боку, цілком очевидно, що далеко не в усіх випадках перекладач виступає у ролі стороннього спостерігача, який фахово декодує смислову структуру вихіднього тексту задля іiї адекватного відтворення засобами цільової мови.

Сприйняття гештальтів вихідної культури в іншому культурному просторі регламентується законом прегнатності або принципом «хорошого гештальту», проте, у контексті цієї статті видається доцільним використовувати поняття «прототипічного гештальту». У широкому розумінні цього терміна прототипічність гештальту пов'язана не стільки з частинами певного об'єкту, скільки 3 його функціями. Адже складові частини не відіграють вирішальної ролі у сприйнятті загальної форми об'єкту. Проте вони мають безпосередній зв'язок з його функцією, яка для багатьох артефактів є так званою «розумною підставою» (raison d'etre) або смислом об'єкта. Існування більшості частин об'єкту зумовлено певною роллю, яку виконує цей об'єкт, тобто його функцією. Ці функціонально вмотивовані частини інтегруються в один гештальт і сприймаються як єдине ціле. Тоді прототип являє собою «вид редукції до релевантних i, здебільшого, візуальних основ, які, однак, сприймаються як єдине ціле» [9, с. 38]. Екстраполюючи логіку цих умовиводів на гештальт поетичного знака, можна дійти висновку, що у даному випадку таким прототипічним гештальтом (або «редукованим» гештальтом, який «включає функціональні частини певного елементу у функціонально врівноважених пропорціях» [8, с. 41] виступає крос-текстовий гештальт, описаний у розділах III і IV, оскільки саме він інкорпорує ту суму фігур, яка визначає специфіку функціонування відповідного гештальту у поетичних текстах певної національно-культурної традиції. При перекладі інтерпретація оригінального «чужорідного» поетичного образу здійснюється за лекалами тих гештальт-формул, що є чіткими, гармонійними і врівно- 


\section{Doubenko Elena}

важеними з позицій поетичної картини світу культури реципієнта, тобто здійснюється доповнення, домальовування або скасування певних складових гештальту вихідного поетичного знака 3 метою прибрати незрозуміле [4, с. 278; 6, с. 213].

Особливе місце у сучасних розвідках з лінгвістики та когнітивної поетики відводиться гештальтистському закону фігури / фона, який постулює сприйняття одного аспекту певного явища або події як фігури / форми або переднього плану, а іншого як фону / основи або тла, на якому ця фігура виділяється. Оскільки гештальт $\epsilon$, насамперед, структурою бачення, або тією свідомістно-перцептивною категорією, що являє собою основу певної «оптики» світосприйняття, то, з лінгвістичного погляду, будь-яка національна мова є «сукупністю когнітивно- відображальних фігур, виділених iï носіями на фоні великої кількості інших виражальних елементів». Відповідно, специфічні характеристики мовних картин світу можна визначити з позицій гештальт-теорії, позаяк вони зумовлюються, по-перше, різними гештальтами, сформованими у різних мовних колективах, а, по-друге, виділенням на однаковому фоні різних фігур [1, с. 332, 219, 207]. У цій статті під фігурою гештальт-структури поетичного знака розуміється контекстуально актуалізований сегмент концептуального змісту певного поетичного гештальта.

\section{3. Деконструкція гештальт-структури вихідного поетичного знака}

Розглянемо 3 цього погляду широко відомий вірш Емілі Дікінсон There's a certain slant of light та його український переклад, виконаний Марією Габлевич. Стрижневий образ вірша заявлено у вихідному тексті двічі: в заголовку та в першому рядку - це стародавній, універсальний для світової літератури образ світла (у даному випадку, сонячного світла), який у незчисленній кількості контекстів виступав метафоричним синонімом найсуттєвіших в духовному житті людини понять - Бога, любові, щастя, віри. Однак у вірші Емілі Дікінсон цей традиційно позитивний символ піддається переосмисленню і виступає носієм якогось незбагненного болю, суму, що позбавляє душевного спокою і виявляється загрозливо-несьогосвітнім, жахаючим, спорідненим зі смертю: 
There's a certain slant of light,

Winter afternoons,

That oppresses like the heft

Of cathedral tunes.

Heavenly hurt it gives us.

We can find no scar

But internal difference

Where the meanings are.

None may teach it anything

'Tis the seal despair,

An imperial affliction

Sent us of the air.

When it comes the landscape listens,

Shadows hold their breath,

When it goes 'tis like the distance

On the look of death.

(MB, p. 189)

Поезія Емілі Дікінсон завжди оцінювалася дослідниками як така, що значно випередила свій час за емоційною навантаженістю та напруженістю почуттів. Адже ламана “нервова" форма вірша, рваний синтаксис, телеграфічність стилю - все це типові риси поезії двадцятого, а не дев'ятнадцятого століття, до якого належала Емілі Дікінсон. Фігура «агресивність, руйнівна сила, насилля» $є$ прототипічною для чоловічого гештальту поетичного знаку SUN в англомовній поетичній картині світу XX століття. Негативна забарвленість світлової метафори є органічною частиною ідіолектів багатьох англійських а, особливо, американських поетів, які пов'язують світло з агресією, ворожістю та насильством. В основі глибинної семантики їхніх творів часто лежать такі концептуальні метафори як : SUN = КАРАЛЬНА СИЛА, SUN = ЦЕ БІЛЬ, SUN = ЗНАРЯДДЯ НАСИЛЬНИЦЬКИХ ДІЙ; ІНСТРУМЕНТ, ЯКИЙ ЗАВДАЄ ФІЗИЧНОГО БОЛЮ, SUN = РУЙНІВНА СУТНІСТЬ, $\mathrm{SUN}=$ ВОРОЖА СУТНІСТЬ [3, с. 276-277].

Проте переосмислення позитивності світлового образу в оригіналі відбувається у дуже обережний спосіб. Поміркована тональність поезії Емілі Дікінсон є несумірною з різкими метафоричними формулами американських поетів двадцятого століття на кшталт: The 


\section{Doubenko Elena}

sunlight pierced my vitals like a knife (J. Wain) [NMP, $p$. 79]; razor ray of the sun... (Ch. Olson) [NAP, $p$. 144]; sun was over our town; it was like a blade. (W. Stafford) [CAP, p.310]; To raise tomorrow's city to the sun // That never sets upon hell-fire streets // Of Boston, where the sunlight is a sword // Striking at the withholder of the Lord (R.Lowell) [CAP, p. 196]; The ache of sunshine stops. // God is gone. God is gone. (J.Spicer) [NMP, p. 205]; Spears of sun striking the water (A. Rich) [FB, p.798]; Sun struck the water like a damnation. (S. Plath) [SPSP, $p$. 19]; I have suffered the atrocity of sunsets. // Scorched to the root. // My red filaments burn and stand, a hand of wires (S. Plath) [SPSP, p. 510].

На тлі наведеної низки поетичних контекстів, які наочно демонструють тенденцію до різкої негативізації образу світла, що відбулася в художній свідомості XX століття, досить прозорою $\epsilon$ паліативність негативного світлового образу в поезії Емілі Дікінсон. Негативне тлумачення зимового світла в іiі вірші There's a certain slant of light виступає своєрідним буферним контекстом між абсолютною позитивністю світлових образів в англомовній романтичній поезії XIX століття та представленням світла як руйнівної, зловісної сили в поетичних твоpax XX століття.

У поезії There's a certain slant of light йдеться про те, що не саме світло, а певний його нахил, погляд, тон [slant] пригнічує душу [oppresses], наче тяжкі акорди соборного органу [the heft of cathedral tunes], але цей біль має небесне походження [heavenly hurt], тому він не залишає шрамів, і лише перебудовує в нас щось найістотніше, на рівні смислу [But internal difference // Where the meanings are]. Провідна концептуальна метафора LIGHT = ДУШЕВНА ПРИГНІЧЕНІСТЬ пізніше підсилюється ствердженням споріднених настроїв розпачу і безвиході ['Tis the seal despair], а також піднесеного суму і скорботи [An imperial affliction // Sent us of the air], відповідно, концептуальні метафори: LIGHT = ЦЕ БЕЗНАДІЯ та LIGHT = ЦЕ ТУГА. Кульмінаційним моментом у композиції оригінального вірша $€$ його останні рядки, в яких вищеописаний душевний стан, спричинений спогляданням якогось дивного сонячного світла, пов'язується з образом смерті [When it goes 'tis like the distance // On the look of death]. Таким чином, в оригінальному тексті гештальт поетичного знака LIGHT містить фігуру «душевна пригніченість, депресивність».

Аналіз ширшого контексту творчості Емілі Дікінсон дозволяе стверджувати, що загострена негативність образу світла загалом не 
притаманна ідіостилю цієї поетеси, хоча тема світла й посідає важливе місце в іiі поетичних творах. Про небайдужість Дікінсон до світлових образів свідчить наявність в її творчій спадщині цілої низки віршів, в яких вони відіграють роль ключових, камертонних елементів. Це поезiї, в котрих: надається опис сходу та заходу сонця (I'll tell you how the Sun rose) [AP, p.243], захід сонця уподібнюється згасанню людського життя (The Sun kept setting - setting - still) [AP, p. 286], поети порівнюються із сонцем (The Poets light but lamps -) [AP, p. 296], представлено розгорнутий метафоричний опис молодого місяця (The Moon upon her fluent Route) [AP, p. 308].

Усі перелічені вірші характеризуються класичним трактуванням світлового образу: це - звернення до світла як до символу натхнення, джерела життя на землі, замилування величністю залитих сонячним сяйвом пейзажів, використання властивих ще архаїчній свідомості метафор, наприклад, опис заходу сонця як нагадування про смертність людини, ії близького відходу у вічність. Проте Емілі Дікінсон $є$ авторкою ще одного вірша, настільки суголосного за тематикою, структурою i, деякою мірою, за настроєм до вище проаналізованого “There's a certain slant of light", що його можна було б вважати своєрідною варіацією останнього. Єдина фактична розбіжність полягає в тому, що причиною душевного збентеження та неспокою в поезії “There's a certain slant of light" виступає незбагнений тон зимового світла, а у вірші “A light exists in Spring" - весняного. Разом з тим ці дві поезії значно різняться за метафоричним трактуванням світла:

A light exists in Spring

Not present on the Year

At any other period -

When March is scarcely here

A color stands abroad

On Solitary Fields

That Science cannot overtake

But Human Nature feels.

It waits upon the Lawn,

It shows the furthest Tree

Upon the furthest Slope you know

It almost speaks to you. 


\section{Doubenko Elena}

Then as Horizons step

Or Noons report away

Without the Formula of sound

It passes and we stay -

A quality of loss

Affecting our Content

As Trade had suddenly encroached

Upon a Sacrament.

[VTG, p. 293]

Якщо в поезіі “There's a certain slant of light” серцевий щем є безпосереднім породженням особливої тональності світла, то вірш “A light exists in Spring” відтворює атмосферу душевної порожнечі, пов'язану з відчуттям втрати чогось найсуттєвішого після повільного зникнення сонячного світла.

Отже, можна констатувати, що увесь контекст творчості Емілі Дікінсон свідчить про вірність поетеси традиційному символічному та метафоричному трактуванню світла; єдина ж спроба осмислити негативність зимового світла робиться в дуже обережний спосіб. Але навіть такий алгоритм розвитку ключового образу вірша - сонячного світла - не є прийнятним 3 погляду канонів поетичної картини світу цільової культури, оскільки гештальт поетичного знака LIGHT у тексті оригіналу не співвідноситься з усталеним гештальтом поетичного знака СОНЦЕ в україномовній традиції, котрий характеризується наявністю таких однозначно позитивних за емоційним потенціалом фігур як «життсдайність, батьківство», «божественність, владність», «зрячість», «озвученість, музикальність», «веселість» [3, с. 280-281]. Це спонукає перекладачку до внесення достатньо радикальних коректив у ієрархію образів вірша. Марія Габлевич по суті підміняє головний образ першотвору «світло», низводячи його до другорядного і висуваючи на перший план образ зимнього дня:

Зимній день - буває - гляне

Променем останнім -

Так щзо вдарить в саме сериче-

Наче грім органів.

Рана його чудотворна -

Ти не знайдеш знаку -

А тільки там де сутності- 


\section{Chapter «Philological sciences»}

Замемить інако.

Не збагнути изього щему

Це - вишній відчай,

Небесами послана

Царствена печаль.

Прийде - все довкілля нишкне,

Тіні мруть і мерхнуть -

А відхід їі величний-

Як хода у смерті.

[ДЛ, с. 258]

Завдяки такій перекладацькій аберації гештальт сонячного світла у цільовому тексті позбавляється фігури «душевна пригніченість, депресивність» за рахунок своєрідного «делегування» цієї фігури до складу гештальту ЗИМНІЙ ДЕНЬ. Саме образ зимового дня здобуває центральну позицію у художній семантиці твору, про що свідчить його винесення у заголовок та першій рядок твору замість того оригінального світлового образу, навколо якого, власне, й побудовано увесь вихідний поетичний текст. При цьому перекладачка вдається навіть до більш радикального трактування негативності ключового образу, ніж Емілі Дікінсон. Замість авторських півтонів вона вживає різкі контрастні метафори: зимовий день вдаряе в саме серце, наче грім органів. Тому серед значень слова hurt, яке перекладається і як "біль", і як "рана", природнім в даному “силовому” контексті є вибір варіанту "рана": (Heavenly hurt it gives us. // We can find no scar... Рана його чудотворна - // Ти не знайдеш знаку-).

Потрібно зазначити, що нівелювання стрижневого образу вихідного поетичного тексту здійснюється у перекладі ще й через зміну лексичного репрезентанта поетичного концепту СВІТЛО. Якщо в оригіналі авторка веде мову про сонячне світло, гештальт якого сформувався на основі надзвичайно потужної історико-культурної традиції в обох поетичних картинах світу - англомовній та україномовній, то у цільовому тексті з'являється не такий всеосяжний, можна сказати, усічений образ світла: промінь, і це значно редукує парадигму фігур у структурі гештальту цільового поетичного знака.

Крім того, у виконаному Марією Габлевич перекладі спостерігається відсутнє в оригіналі означення лексеми, що позначає світло: прикметник «останній» (Зимній день - буває - гляне // Променем 


\section{Doubenko Elena}

останнім...). Цей елемент позбавляє світловий образ друготвору будь-яких можливих негативних асоціацій і дозволяє закріпити статус причини тужливого настрою суцільно за зимовим днем, адже єдиний негативний момент, пов'язаний зі світловим образом (променем) базується на тому, що світло нетривалого зимового дня вже готово зникнути, поступаючись гнітючій темряві. Характер внесеної у цільовий текст зміни є цілком очевидним: це самовільне перекладацьке додавання художнього елементу, адже оригінальний текст не містить жодного натяку на останні проміні сонячного світла. У першотворі йдеться про світло зимового дня як такого (Winter afternoons), оскільки під поняттям afternoon розуміють увесь проміжок часу від вранішніх до вечірніх годин.

Нарешті, варте уваги не лише вилучення фігури «душевна пригніченість, депресивність» 3 гештальту поетичного знака світло у перекладі, але й актуалізація у його складі фігур «зрячість» та «музикальність»: СВІТЛО - ЦЕ ЗВУК - Зимній день - буває - гляне // Променем останнім - // Так щзо вдарить в саме серие - // Наче грім органів. Якщо фігура «зрячість» взагалі відсутня у складі оригінального гештальту, то фігура «музикальність» хоча й наявна у вихідному поетичному тексті, але іiі зв'язок з образом світла не є таким тісним і безпосереднім, як у цільовому тексті. Адже в оригіналі світло виступає суб'єктом дії, являючи собою першоджерело скорботного настрою, і тому найбільш вагома фігура гештальту поетичного знака LIGHT «душевна пригніченість, депресивність» актуалізується вже на самому початку твору через дієслово «орpress»: There's a certain slant of light, // Winter afternoons, // That oppresses like the heft // Of cathedral tunes. При цьому семантика музикальності асоціюється зі світлом у більш віддалений спосіб: світло пригнічує душу подібно до акордів органної музики. Натомість у друготворі світло перетворено на знаряддя дій зимового дня (Зимній день - буває - гляне // Променем останнім - // Так щзо вдарить в саме серие - // Наче грім органів), тому в цільовому тексті воно перебуває у прямому семантичному зв'язку зі звуками органу.

Усі вищеописані перекладацькі рішення призводять до втрати гостроти переживання, що виникає саме завдяки незвичному використанню світлового образу у першотворі: адже мова йде, врешті решт, не про зимній день, а про якусь особливу тональність світла. Запропоноване перекладачкою зміщення семантичних акцентів виходить за 
рамки неточної інтерпретації безпосередньо даного поетичного тексту, оскільки через універсальність головного образу цю поезію можна розглядати як одну з ланок у довжелезній низці контекстів світової літератури. Трактування образу світла в ньому заперечує свої численні попередні інтерпретації. Проте образ не відмінено повністю - його лише інвертовано, переведено від нахилу світла, типового для зимового дня, до самого зимового дня, який ранить серце останнім променем.

\section{4. Заміна вихідного поетичного знака}

У попередньому підрозділі було розглянуто приклад перекладацької аберації, спричиненої непрототипічністю певних фігур у складі гештальту вихідного поетичного знака. Проте у перекладацькій практиці трапляються й такі випадки, коли непрототипічною виявляється уся гештальт-формула вихідного поетичного знака, внаслідок чого перекладацька аберація набуває більш радикального характеру. Наочний приклад результатів саме такого поетичного паралаксу надає виконаний В. Марачем українській переклад вірша Роберта Фроста “One acquainted with the night".

В основу цієї ліричної поезії покладено опис незвичайного переживання, пов'язаного з осягненням певних глибинних першоджерел власної душі.

ONE ACQUAINTED WITH THE NIGHT

I have been one acquainted with the night.

I have walked out in rain - and back in rain.

I have outwalked the furthest city light.

I have looked down the saddest city lane.

I have passed by the watchman on his beat

And dropped my eyes unwilling to explain.

I have stood still and stopped the sound of feet

When far away an interrupted cry

Came over houses from another street.

But not to call me back or say good-by;

And further still at an unearthly height,

One luminary clock against the sky

Proclaimed the time was neither wrong nor right

I have been one acquainted with the night.

[MB, p. 248] 


\section{Doubenko Elena}

Вірш побудовано на розповіді про поступове відчуження ліричного героя твора від реальності, від суєтного світу смертних. Спочатку він залишає позаду себе межі міста, його вогні та вулиці, потім відчуває небажання спілкуватися зі сторожем - єдиною людиною, яку можна зустріти у нічний час на віддаленій околиці міста, а після цього починає розуміти, що він більше не є частиною повсякденої, буденної реальності. Заключна частина оригінальної поезії співвідноситься вже 3 площиною «неземної вишини», яка виступає символом іншого світу, репрезентованого у вірші кульмінаційним образом місяця (One luminary clock against the sky // Proclaimed the time was neither wrong nor right), що є другим за своєю художньою значущістю після стрижневого образу твору - ночі.

В архетипічному сенсі центральний образ вірша має двоїсту природу, адже Ніч, з одного боку, символічно репрезентує смерть, а з іншого боку, втілює стихію несвідомого та жіночого (архетип Матері). Тотожні архетипічні сугестії виявляє й образ Місяця, позаяк в контексті англо-американської поетичної традиції гештальт-формула вихідного поетичного знака MOON містить фігури «причетність до небуття, потойбічність» (архетип Смерті) та «фемінінність» (архетип Жінки). Проте, як свідчить аналіз глибиної семантики оригінального твору, ґештальт-формула вихідного поетичного знака MOON не обмежується лише згаданими фігурами. Метафорична репрезентація місяця у вигляді циферблату, до якої вдається автор оригінального тексту, пов'язує на рівні художнього смислу образ місяця з концептом часу, стверджуючи позачасовість того світу, що перебуває під владою Ночі. За текстом першотвору сяючий у небі годинник вказує час, який не має жодного відношення до темпоральних характеристик повсякденного життя: це по суті та відсутність часових будь-яких координат, що дорівнює вічності.

Таким чином символічна представленість часу в образі сяючого у небі циферблата вже наступної миті перетворюється на знак відсутності реального часового виміру. Тому небесний годинник $з$ цього вірша Роберта Фроста можна цілком обгрунтовано порівняти з широко відомою художньою метафорою - текучими циферблатами Сальвадора Далі. Це надає всі підстави констатувати актуалізацію фігур «нереальність, оманливість» та «мінливість, зрадливість» (архетип метаморфози) у гештальт-формулі вихідного поетичного знака MOON. Крім того, глибока символічність оригінального твору вочевидь санкціонує й гіпотетичну можливість акту- 
алізації ще двох фігур з прототипічної гештальт-формули поетичного знака MOON в англо-американській літературній традиції: «божевілля, химерність», «пророкування, сила яснобачення».

Актуалізація всього вище окресленого спектру архетипічних сугестій, що містяться в прототипічній структурі гештальт-формули поетичного знака MOON, уможливлює художню репрезентацію емоційного досвіду причетності ліричного героя першотвору до царини незбагненого, поетичне унаочнення того «знайомства $з$ ніччю», яке має неминучі наслідки для внутрішнього життя особистості. Водночас усі вищезазначені сугестії $є$ позбавленими прототипічної асоціативної співвіднесеності з концептом «місяць» в україномовній поетичній картині світу. В українській поезії провідні елементи у гештальт-формулі поетичного знака МІСЯЦЬ безпосередньо визначаються чоловічим родом слова «місяць» в українській мові; це такі фігури як «молодість, краса», «старість, немічність», «залежність, не самодостатність», «озвученість, музикальність», «агресивність, руйнівна сила» [3, с. 295-299].

Зазначені кардинальні розбіжності у гештальт-формулах поетичних знаків MOON та МІСЯЦь спонукають перекладача до заміни непрототипічного для цільової культури образу місяця, актуалізованого в оригінальному творі, на образ зірок, що у даному поетичному контексті, за думкою В.Марача, має бути більш зрозумілим для читачів перекладу:

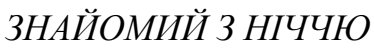

Знайомий з ніччю я уже давно.

Виходив я й вертався під дощем,

Та довго ще світилося вікно,

Задумавшись, не відповів йому,

Як сторож стрівсь, закутаний плащем,

Знов зупинивсь, вслухаючись в пітьму:

Позаду в місті кликали когось,

Збентежився, не знаю сам, чому;

Та не мене гукав далекий хтось.

A угорі, де зоряне рядно,

Мов цифрерблатом просіяло щось.

Спішить чи відстає він - все одно.

Знайомий з ніччю я уже давно 


\section{Doubenko Elena}

Важливо зауважити, що очевидна позитивність образу зірок, на якому зупиняє свій вибір перекладач ( $A$ угорі, де зоряне рядно, // Мов uзиферблатом просіяло щзось), виступає органічною частиною загальної стилістичної тональності цільового тексту, котрий помітно відрізняється за своїм емоційним регістром від першотвору.

Так, приміром, переклад значно зміщує оригінальні смислові акценти рядка «I have outwalked the furthest city light», адже «вийти за межі міста, залишивши позад себе світло найвіддаленіших околиць» й означає реальне знайомство з ніччю, непроглядною і безлюдною темрявою. Натомість переклад В.Марача «Виходив я й вертався під дощеем, // Та довго ще світилося вікно», можна сказати, містить навпаки досить оптимістичні ноти, як і сталий образний вираз «світло у вікні / єдине світло у вікні», що має конотації надії, домашнього затишку та тепла. Достатньо безжурно звучить у перекладі й рядок про час, який вказує небесний годинник: Cniшuть чи відстає він - все одно. Таке перекладацьке рішення вочевидь позбавляє згадку про сяючий у небі циферблат усіх майже біблійних сугестій вічності, позачасовості нічного простору, в якому опинився герой поезії. Замість цього у цільовому тексті на перший план виходить суб'єктивна думка розповідача, у якого особисто не викликає жодного занепокоєння або будь-якого іншого емоційного відгуку ані час, що показує годинник, ані дещо незвичний вигляд останнього.

\section{5. Висновки}

Відхилення від першотвору, що трапляються у тексті поетичного перекладу, зумовлюються цілим спектром причин, до яких належать не лише розбіжності у системах вихідної та цільової мови, але й ті особливості перекладацької інтерпретації, котрі є наслідком менталітетних відмінностей між культурами автора оригінального тексту та перекладача.

Будучи представником іншого концептуального простору, а, отже, й іншої герменевтичної установки, перекладач доволі часто робить свій вибір підсвідомо, мимоволі інтерпретуючи смислові акценти першотвору у річищі рідної йому мовної та культурної традиції. Саме такі світоглядні, свідомі або несвідомі відхилення від оригінального поетичного тексту, до яких вдається перекладач, передаючи художній зміст першотвору, й отримали назву перекладацьких аберацій. 


\section{Chapter «Philological sciences»}

Відтворюючи образність вихідного поетичного тексту автор друготвору так чи інакше орієнтується на прототипічні гештальти поетичної картини світу культури реципієнта. При цьому в контексті цього дослідження прототипічний гештальт визначається як крос-текстовий гештальт поетичного знака, що інкорпорує у своїй структурі певну суму сталих елементів когнітивного змісту або фігур, які зумовлюють специфіку функціонування відповідного поетичного знака у художніх текстах даної національно-культурної традиції.

Таксономія перекладацьких відхилень або аберацій включає цілий спектр трансмутацій вихідного поетичного знака, скерованих на відновлення його світоглядної «впізнаваності» у цільовому лінгво-культурному просторі. Перекладацькі аберації гештальт-структури вихідного поетичного знака можуть проявлятися у таких трансформаціях як деконструкція гештальт-структури вихідного поетичного знака, вмотивована поетичними нормами цільової культури, а також заміна вихідного поетичного знака на той поетичний знак, що перебуває в узгодженні з приписами концептуальної картини світу цільової культури.

Описані у статті види перетворень гештальт-формули вихідного поетичного знака не є єдино можливими перекладацькими абераціями, які мають місце під час іншомовного перекодування вихідних концептів, наділених специфічним художньо-естетичним та етнокультурним змістом. Список подібних трансформацій, безперечно, залишається відкритим і тому подальші дослідження у цьому напрямку дозволять виявити інші різновиди перекладацьких аберацій, що являють собою переконливу ілюстрацію тяжіння авторів цільових поетичних текстів до лекал власної історико-культурної традиції.

\section{Список літератури:}

1. Безпаленко А.М. Слово в аспекті гештальт-теорії. Принцип суміжності: дис. ... д-ра філол. наук: 10.02.15. / Безпаленко Анатолій Мілетійович. Київський національний університет імені Тараса Шевченка. - Київ, 2010. $491 \mathrm{c}$.

2. Большой немецко-русский словарь. В двух томах / Е.И. Лепинг, Н.П. Страхова, Н.И. Филичева, М.Я. Цвиллинг, Р.А. Черфас. Под руководством д.ф.н., проф. О.И. Москальской. Издание 2-е. - М.: Издательство «Русский язык», 1980. - 760 с. (т. 1), 656 с. (т. 2).

3. Дубенко О.Ю. Порівняльна поетика: типологічний та перекладознавчий аспекти: Монографія / О.Ю. Дубенко. - К.: Видавничий дім Дмитра Бураго, 2015. - 532 c. 


\section{Doubenko Elena}

4. Лановик М. Перекладознавчі проблеми компаративістики крізь призму літературознавчих теорій / Навч. посібник / Ред. Р.Т. Гром'як / Мар'яна Лановик // Літературознавча компаративістика. - Тернопіль: Редакційновидавничий відділ ТДПУ, 2002. - С. 272-309.

5. Маковский М.М. Удивительный мир слов и значений. Иллюзии и парадоксы в лексике и семантике. - М.: Высшая школа, 1989. - 201 с.

6. Пригодій С.М. Фронтирний неоромантизм у літературі США. Різночитання; Монографія. / С.М. Пригодій - К.: КНУ імені Тараса Шевченка, видавництво Свропейського університету, 2010. - $231 \mathrm{c}$.

7. Guberman Sheila. Algorithmic Analysis of "Good Continuation" Principle / Sheila Guberman // Gestalt Theory. - 2007. - Vol. 29. - No. 2. - Pp. 148-168.

8. Ungerer F. Introduction to Cognitive Linguistics / Friedrich Ungerer, HansJörg Schmid. - London: Longman, 1996. - 218 p.

9. Ungerer F. An Introduction to Cognitive Linguistics / Friedrich Ungerer, Hans-Jörg Schmid. - Pearson Education, 2006. - 384 p.

10. Wertheimer M. Laws of Organization in Perceptual Forms (1923)/ M. Wertheimer // A Source Book of Gestalt Psychology. Ed. by W. Ellis. - London: Routledge \& Kegan Paul, 1997. - Pp. 71-88.

\section{References:}

1. Bezpalenko A.M. (2010). Slovo v aspekti geshtal't-teorii. Prynzyp sumizhnosti [Word in a gestalt-theoretical aspect. The principle of contiguity]: thesis for a doctor degree in philology. Kyiv. Taras Shevchenko National University of Kyiv.

2. Bolshoi nemetsko-russkij slovar. V dvukh tomakh (1980). [New GermanRussian Dictionary] / E.I. Leping, N.P. Strakhova, N.I. Filicheva, M.Ya. Tsvilling, R.A. Cherfas. Izdanie 2. M.: Izdatel'stvo "Russkij yazyk" (Vol. 1).

3. Doubenko E. (2015). Comparative poetics: typological and translatological aspects. (Monograph) Kyiv: Vydavnychyi dim Dmytra Burago. (in Ukrainian)

4. Guberman Sheila (2007). Algorithmic Analysis of "Good Continuation" Principle. Gestalt Theory. Vol. 29. No. 2. Pp. 148-168.

5. Lanovyk M. (2002). Perekladoznavchi problemy komparatyvistyky kriz' pryzmu literaturoznavchykh teorij [Translatological issues of comparative studies in the light of literary criticism theories]. Comparative studies in literary criticism. Ternopil: Redaktsijno-vydavnychyj viddil TDPU, pp. 272-309. (in Ukrainian)

6. Makovskij M.M. (1989). Udivitelnyj mir slov i znachenij. Illjuzii i paradoksy $\mathrm{v}$ leksike i semantike [The amazing world of words and meanings.Illusions and paradoxes in lexis and semantics]. M.: Vysshajya shkola. (in Russian)

7. Pryhodij S.M. (2010). Frontyrnyj neoromantyzm u literaturi SSHA. Riznochytannya [Frontier neoromanticism in the US literature. Variant readings]. (Monograph). K.: KNU imeni Tarasa Shevchenka, vydavnytstvo Evropejskogo universytetu. (in Ukrainian)

8. Ungerer F. (1996). Introduction to Cognitive Linguistics / Friedrich Ungerer, Hans-Jörg Schmid. London: Longman.

9. Ungerer F. (2006). An Introduction to Cognitive Linguistics / Friedrich Ungerer, Hans-Jörg Schmid. Pearson Education. 
10. Wertheimer M. Laws of Organization in Perceptual Forms (1923). A Source Book of Gestalt Psychology (1997). Ed. by W. Ellis. London: Routledge \& Kegan Paul, pp. 71-88.

\section{Джерела ілюстративного матеріалу:}

1. ДЛ = Дікінсон Е. Лірика. - К.: Дніпро, 1991. -252 с.

2. AP =American Poetry: The Nineteenth Century. V. 2. - The Library of America, 1993. $-520 \mathrm{p}$.

3. $\mathrm{CAP}=$ The Contemporary American Poets. American Poetry since 1940 / Ed. by Mark Strand. - N.Y.: Meridian Books, 1990. - 560 p.

4. $\mathrm{FB}=$ The Faber Book of 20-th century women's poetry / Edited by Fleur Adcock. - L., 1987. -903 p.

5. $\mathrm{M}=$ Marach, Victor. Poetic studio. Electronic resource: maysterni.com/user. php?id $=629 \&=18 \mathrm{rub}=1238$ st.

6. $\mathrm{MB}=$ The Mentor Book of Major American Poets /Edited by O.Williams and E.Honig. - Ontario. New American Library, 1962.-535 p.

7. NAP $=$ The New American Poetry $/$ Edited by Donald M.Allen. N.Y.: Evergreen Books LTD, 1960. -452 p.

8. NMP $=$ The New Modern Poetry. An Anthology of American and British Poetry since World War II. / Ed. by M.L. Rosenthal. - N.Y.: Oxford University Press, 1969. $-289 \mathrm{p}$.

9. $\quad$ SPSP $=$ Sylvia Plath's Selected Poems chosen by Ted Hughes. - Faber and Faber, 1985. $-85 \mathrm{p}$.

10. $\mathrm{VTG}=$ The Voice That is Great Within Us. American Poetry of the Twentieth Century / Ed. by Hayden Carruth. -N.Y.: Bantam Books, 1981. - 722 p. 